\title{
VARIATIONS IN THE SPATIAL DISTRIBUTION OF AREAS OF ECONOMIC GROWTH AND STAGNATION IN POLAND: DETERMINANTS AND CONSEQUENCES
}

\author{
PAWet ChURSKI \\ Institute of Socio-Economic Geography and Spatial Management, Adam Mickiewicz University, Poznań, \\ Poland \\ Manuscript received: October 4, 2013 \\ Revised version: March 13, 2014
}

\begin{abstract}
CHURSKI P., 2014. Variations in the spatial distribution of areas of economic growth and stagnation in Poland: Determinants and consequences. Quaestiones Geographicae 33(2), Bogucki Wydawnictwo Naukowe, Poznań, pp. 63-77, 6 tables, 6 figs. DOI 10.2478/quageo-2014-0016, ISSN 0137-477X.

AвSTRACT: This study seeks to identify the spatial distribution of and changes in areas of economic growth and stagnation in Poland resulting from spatial differences in the process of the country's socio-economic advancement. The research covered two spatial systems, NUTS 2 and NUTS 4, and embraced the following steps: (1) identification of the spatial distribution of areas of economic growth and stagnation, by region and subregion, and of its determinants; (2) analysis of variations in the spatial distribution of areas of economic growth and stagnation, by region and subregion, and of its consequences; and (3) conclusions from the development trajectories identified and recommendations for intervention measures to be taken under cohesion policy.
\end{abstract}

The results presented here come from one of the stages of a research conducted under the project Socio-economic development and the formation of areas of economic growth and stagnation, funded by the National Science Centre (N N306 791940). The project is implemented by a team of staff members of the Department of Regional Analysis of the Institute of Socio-Economic Geography and Spatial Management, Adam Mickiewicz University in Poznań, headed by the present author.

KEY WORDS: differences, growth, stagnation, areas, region, subregion, Poland

Pawet Churski, Department of Regional Analysis, Institute of Socio-Economic Geography and Spatial Management, Adam Mickiewicz University, ul. Dzięgielowa 27, 61-680 Poznań, Poland; chur@amu.edu.pl

\section{Introduction}

In socio-economic development, polarisation is a characteristic feature of this process. Its consequence is the presence of growth and stagnation areas in economic space. The distribution of those areas and its unevenness depend on differences in the impact of development factors, which lead to convergence or divergence in development levels. While differences in development as such are acceptable in the conditions of a market economy, widening disparities in the development of individual areas can lead to many undesirable consequences and are perceived as one of the basic barriers to the proper operation of the economy (Krugman 1995; Faludi 2006; Molle 2007; Meijers et al. 2007; Martin, Sunley 2011). This makes it necessary to take intervention measures under cohesion policy which, irrespective of the model adopted (an equalising or a polarisation-diffusion one), is intended to achieve the convergence of development at all spatial levels (Reshaping Economic Geography 2009; Cohesion Policy Support... 2010; Fifth Report... 2010; Regional Development Policies... 
2010; Regional Policy... 2011; Shrinking regions... 2008; Pakiet legislacyjny 2014-2020).

This paper seeks to identify the state of and changes in the spatial distribution of areas of economic growth and stagnation in Poland that results from spatial differences in the country's socio-economic development. The research embraced the following stages:

1. Identification of the spatial distribution of areas of economic growth and stagnation, by region and subregion, and of its determinants;

2. Analysis of variations in the spatial distribution of areas of economic growth and stagnation, by region and subregion, and of its consequences; and

3. Conclusions from the development trajectories identified and recommendations for intervention measures to be taken under cohesion policy.

The analysis covered two spatial systems: of voivodeships (NUTS 2) and of poviats (NUTS 4), and its scope was determined primarily by the availability of statistics. In the research procedure use was made of data published by the Central Statistical Office (GUS) in the framework of its Bank of Local Data. The study period embraced the years 2000-2010.

The results presented here come from one of the stages of a research conducted under the project Socio-economic development and the formation of areas of economic growth and stagnation, funded by the National Science Centre (N N306 791940). The project is implemented by a team of staff members of the Department of Regional Analysis of the Institute of Socio-Economic Geography and Spatial Management, Adam Mickiewicz University in Poznań, headed by the present author.

\section{Spatial distribution of areas of economic growth and stagnation at the regional and local levels}

An analysis of differences in the state of and changes in socio-economic development in Poland required a procedure for describing a set of points (objects) in a multidimensional space. Here the objects were units of the country's territorial division that correspond to the levels NUTS 2 (voivodeships) and NUTS 4 (poviats) in the European Union's Nomenclature of Units for Territorial Statistics. The dimensions describing the location of those objects in the multidimensional space were indices characterising their socio-economic development at concrete time moments in general terms, while the following five aspects were considered in a partial approach:

- population and settlement,

- labour market and structure of economy,

- physical infrastructure and its spatial accessibility,

- financial situation and level of wealth, and

- innovative economy and business environment.

The methods employed in the research procedure were Perkal's synthetic index and cluster analysis. The synthetic index method, termed the $z$-score method in Anglo-Saxon literature (Smith 1972) and Perkal's index method in Polish literature (Kostrubiec 1965; Chojnicki, Czyż 1991), finds application in a synthetic assessment of socio-economic phenomena. Perkal's index is a figure averaging over standardised values of the indices considered (variables describing the location of objects) and can assume values from -3 to 3 . In this research it is treated as a synthetic indicator of the level of socio-economic develop-

Table 1. Structure of the reduced geographical observation base adopted for the regional (NUTS 2) level

\begin{tabular}{|l|c|c|}
\hline \multicolumn{1}{|c|}{ Partial approach } & $\begin{array}{c}\text { Initial set of } \\
\text { variables }\end{array}$ & $\begin{array}{c}\text { Set of variables } \\
\text { after reduction }\end{array}$ \\
\hline Population and settlement & 42 & 16 \\
\hline Labour market and structure of economy & 39 & 15 \\
\hline Physical infrastructure and spatial accessibility & 61 & 15 \\
\hline Financial situation and level of wealth & 27 & 15 \\
\hline Innovative economy and business environment & 14 & 13 \\
\hline General approach & 183 & 74 \\
\hline
\end{tabular}

Source: own compilation 
Table 2. Structure of the reduced geographical observation base adopted for the local (NUTS 4) level

\begin{tabular}{|l|r|r|}
\hline \multicolumn{1}{|c|}{ Partial approach } & $\begin{array}{c}\text { Initial set of } \\
\text { variables }\end{array}$ & $\begin{array}{c}\text { Set of variables } \\
\text { after reduction }\end{array}$ \\
\hline Population and settlement & 19 & 10 \\
\hline Labour market and structure of economy & 16 & 8 \\
\hline Physical infrastructure and spatial accessibility & 28 & 12 \\
\hline Financial situation and level of wealth & 26 & 16 \\
\hline Innovative economy and business environment & 3 & 3 \\
\hline General approach & 92 & 49 \\
\hline
\end{tabular}

Source: own compilation

ment of a given spatial unit (object). It was used to classify the spatial units examined with the help of cluster analysis and the k-means algorithm. Cluster analysis (Tryon 1939; Dymnicki, Henry 2011) is a method widely employed in classifications of spatial units, the classes displaying maximum internal homogeneity in terms of the values of variables used in the analysis and maximum inter-class differences (Palme 1995a, 1995b; Kronhalter 2003; Aumayr 2007; Identyfikacja ... 2009). In the present study, this method is employed to identify clusters with similar values of Perkal's index, so that the variance in each cluster is the smallest (Morrison 1990; Szymla 2000). The aim of econometric analysis was to distinguish three groups of objects:

- with the lowest values - stagnation areas,

- with average values, and

- with the highest values - growth areas.

The analysis embraced the period 2000-2010 and covered all data referring to the examined spatial units available in the Bank of Local Data of the Central Statistical Office.

The research procedure involved three principal stages: selection, grouping, and classification. The first involved the choice of variables describing the level of socio-economic development and was based on autocorrelation analysis and a substantive appraisal. It was assumed that variables showing an autocorrelation of $\mathrm{r}^{2}>0.5$ for at least seven years qualified for removal from further analysis. Each variable recommended for removal was assessed in terms of its impact on the determinants of a given aspect of socio-economic development or its significance in the development process treated in general terms. The result of this substantive assessment was decisive for the final inclusion in, or removal from, further analysis. It was then assumed that the reduction should embrace no less than $50 \%$ of the initial variables. The grouping of objects - spatial units - involved their division into three clusters by the criterion of the greatest similarity of the variables using $\mathrm{k}$-means clustering. At this stage use was made of 'smoothed' k-means clustering performed on the values of Perkal's synthetic index with averaged boundaries ${ }^{1}$. The classification of the examined groups of objects (spatial units) involved interpreting the three clusters distinguished as either areas of economic growth or areas of economic stagnation.

The study was conducted separately for each spatial system under analysis: NUTS 2 and NUTS

1 Initially, at the stage of testing methods, calculations were made using $\mathrm{k}$-means clustering without averaging over the boundaries. Their results were presented in Churski (2012). However, it was decided that, given the great variability of boundaries obtained for the individual years under examination, a more appropriate move from the point of view of statistical theory would be averaging over boundaries. The boundaries are a statistical parameter characterising the distribution of the values of a continuous random variable; here it is Perkal's index. Thus, the mean is an unbiased estimator of this parameter and, on assuming normality of the function estimating this parameter, the theoretical variance of the mean is the smallest (e.g. Morrison 1990). The Shapiro-Wilk test performed for the values of boundaries over the years (for the boundary separating stagnation and transition areas and for one separating transition and growth areas, respectively) did not reveal any departures from normality. In the light of the above, this is a confirmation that the estimators obtained by averaging have the desired statistical properties, and that the method of averaging over the boundaries is correct from the point of view of statistical theory. The results of application of this approach in the research procedure are presented in the next chapter. 


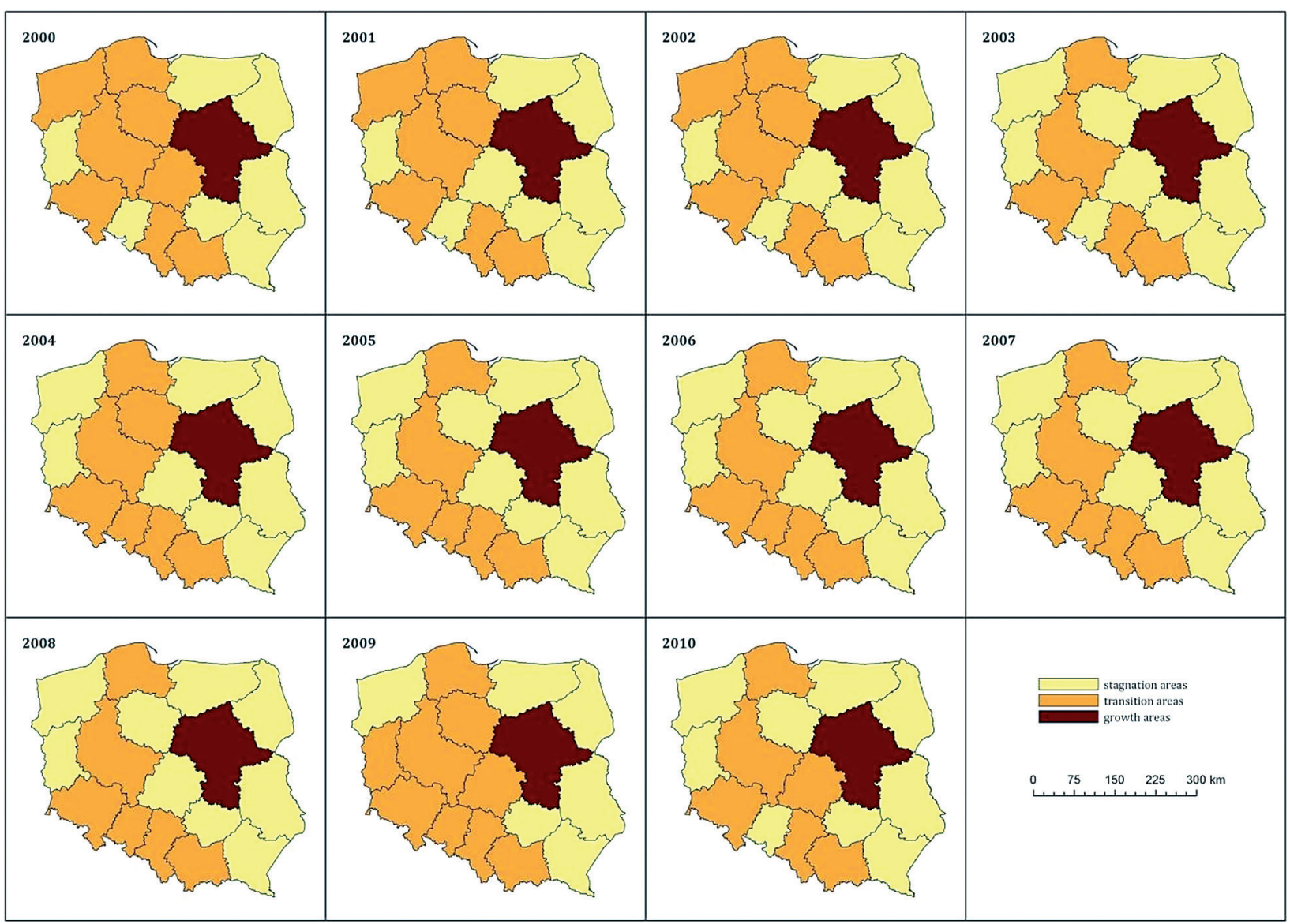

Fig. 1. Distribution of areas of economic growth and stagnation at the regional (NUTS 2) level in the years 2000-2010: a general approach Source: own compilation

4. Its results for 11 time moments in a general approach are presented in Figs 1 and $2^{2}$.

The analysis of spatial differences in the level of socio-economic development in Poland over the years 2000-2010 was carried out for 74 variables describing spatial units at the regional (NUTS 2) level and 49 variables referring to the local (NUTS 4) level. At the regional level, the number of variables describing each of the five analysed aspects of socio-economic development was similar, from 13 (Innovative economy and business environment) to 16 (Population and settlement) (cf. Table 1). Differences in the number of variables were much greater at the local level, where their number ranged from 3 (Innovative economy

2 Because of the limited scope of this article, it was impossible to present the results of a partial approach accommodating each of the five aspects of socio-economic development. However, in the conclusions those results are taken into consideration. and business environment) to 16 (Financial situation and level wealth) (cf. Table 2).

The spatial distribution of growth and stagnation areas at the regional (NUTS 2) level showed great stability over the study period (cf. Fig. 1 ). The only unit identified as a growth region throughout this period by the clustering method used to classify the voivodeships was Mazovia. The class of stagnation regions was more diversified. Throughout the period, stagnation regions included the voivodeships of Lublin, Podlasie, Subcarpathia, Świętokrzyska Land and Warmia-Mazuria, forming a compact area known as 'the eastern wall', as well as Lubuska Land in the west. At times this class also embraced $\mathrm{Ku}$ javia-Pomerania (without the years 2002 and 2004), Łódź (without the period 2009-2010), Opole (without the period 2004-2009), and West Pomerania (without the period 2000-2002). The remaining voivodeships were classified as transition areas. They formed a belt in southern and 
western Poland. When comparing the obtained distribution of areas of economic growth and stagnation in a general approach with the distributions accommodating development differences in the five aspects examined in the project, one can note that the overall distribution of those areas was predominantly determined by differences in financial capital and innovation, and less so by differences in the labour market and physical infrastructure as a condition of spatial accessibility.

The spatial distribution of areas of economic growth and stagnation at the local, or poviat (NUTS 4), level also displayed great stability over the study period (cf. Fig. 2). The smallest class was that of growth areas, which basically included three categories of poviat. The first embraced poviat-ranking towns (municipal poviats), which enjoy the best financial situation of all territorial units in Poland. The second category was the so-called 'raw-materials' poviats where large plants of the extractive industry are located, e.g. Zgorzelec (a mine and a power plant), Lubin (a mine), Legnica (a steelworks), or Bełchatów (a mine and a power plant). The third category included poviats with large, economically thriving entities, e.g. Police with the POLICE S.A. Chemical Works, Kwidzyn with its International Paper Kwidzyn, or Kozienice with ENEA Wytwarzanie S.A. Those types of units classed as growth areas were complemented with non-municipal poviats situated in the immediate neighbourhood of the biggest poviat-ranking towns with which they formed metropolitan areas. They confirmed the diffusion of development from growth areas to those in their hinterland, but this only took place in the largest urban agglomerations and not in medium-sized towns like Suwałki, Słupsk, Piotrków Trybunalski or Kielce, or in 'raw-materials' and 'industrial' poviats like Bełchatów, Zgorzelec or Kozienice. The spatial distribution of growth areas obtained can be described as mosaic-like. Areas of economic stagnation formed a much more sizable class in which non-municipal poviats predominated, especially in eastern and central Poland. Their spatial distribution usually coincided with the relict boundaries (political boundaries from the years 1815-1919) still readily visible in the country's socio-economic space. This class also embraced non-municipal poviats facing deep structural problems produced by a large proportion of former state farms in the ownership structure of their agriculture (e.g. north-western and north-eastern Poland), very small, individually operated farms (the 'eastern wall' poviats), and monofunctional labour markets (scattered throughout the country) whose economic base depended on a single enterprise and whose economic problems, if not downright bankruptcy, affected the socio-economic development of the entire area. The remaining poviats were assigned to the class of transition areas, which clearly dominated in western Poland.

The results obtained for the local level differ from those at the regional one. Here the overall distribution of growth and stagnation areas was largely determined by differences in the demographic situation, which did not play such an important role in diversifying socio-economic development at the regional level. Here also the distribution depended less on differences in the financial situation of local governments and enterprises and on people's wealth than at the regional level, where those factors crucially affected the overall distribution of growth and stagnation areas. It should be emphasised that owing to the highly limited set of variables available for and processed in the analysis at the local level, the close similarity of the overall distribution to that of growth and stagnation areas in the Innovative economy and business environment aspect should be interpreted with great care. The obtained results lead to the conclusion that the analysed partial aspects of socio-economic development differ in their influence on the course of this process at the regional and the local level in a general approach. This will be an object of further detailed studies planned at the stage of identification of factors of socio-economic development in the project the partial results of which are reported in this article.

\section{Variations in the spatial distribution of areas of economic growth and stagnation at the regional and local levels}

The analysis of variations in the spatial distribution of growth and stagnation areas in a general approach had several stages: 


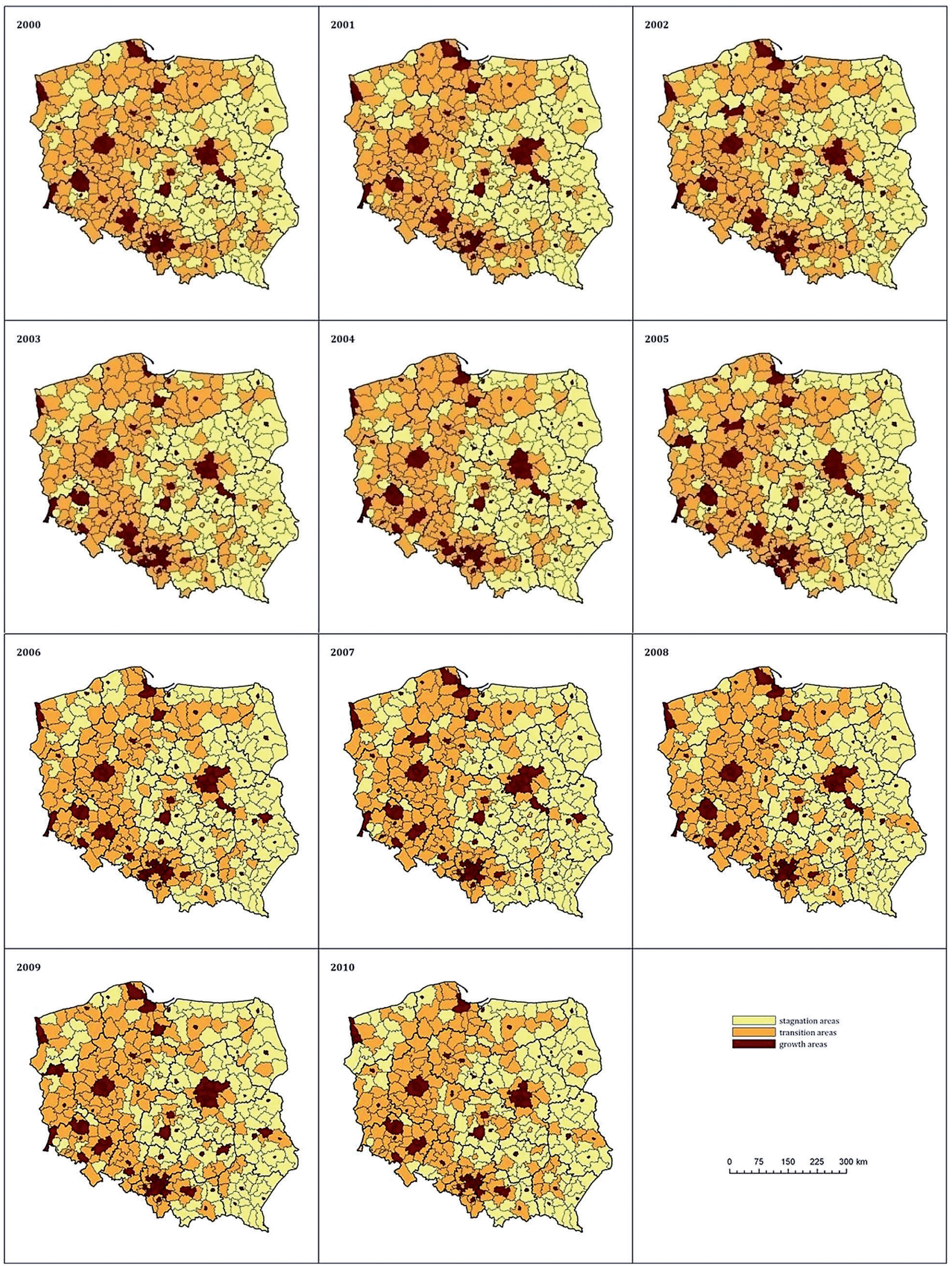

Fig. 2. Distribution of areas of economic growth and stagnation at the local (NUTS 4) level in the years 2000-2010: a general approach 


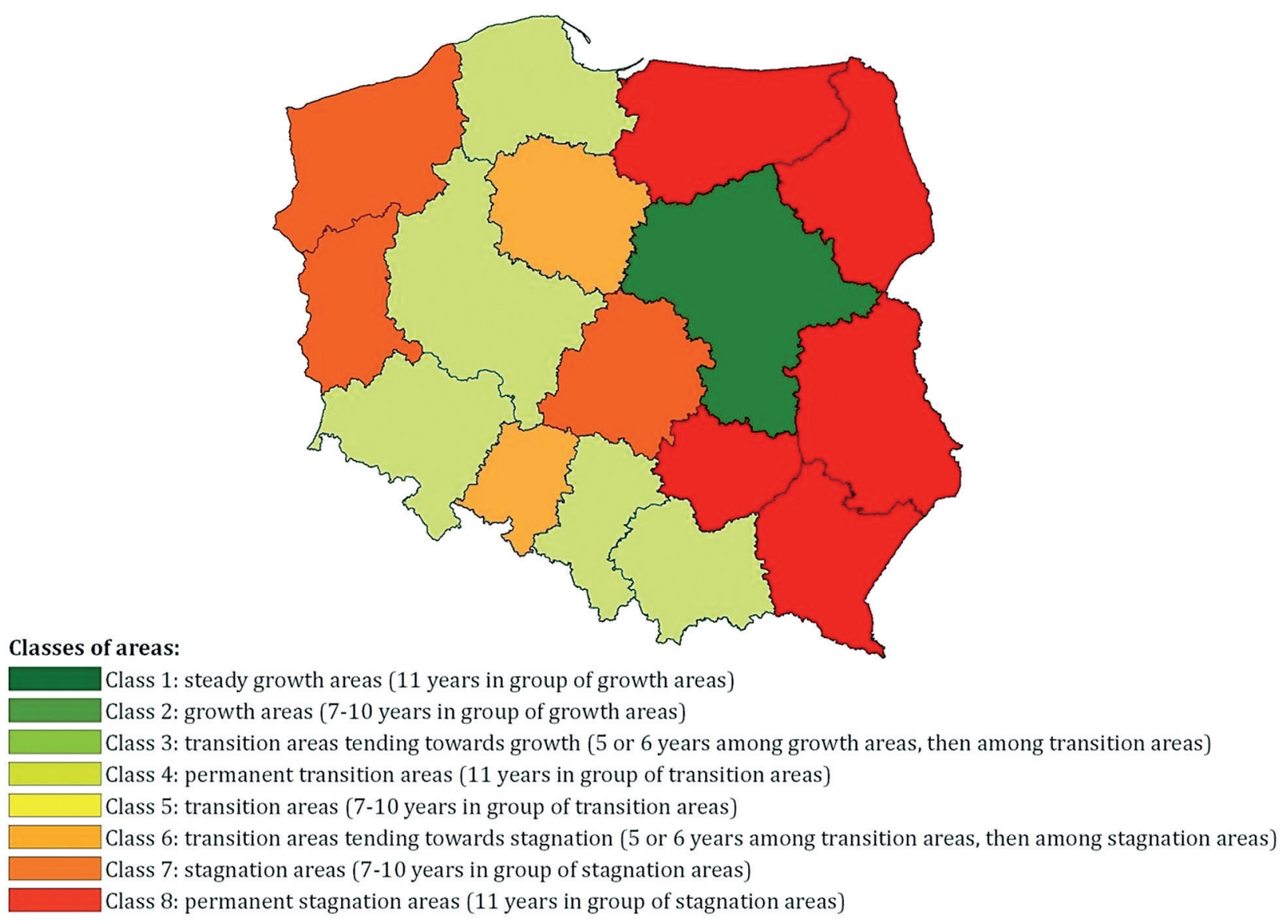

Fig. 3. Spatial distribution of classes of growth and stagnation areas by NUTS 2 units: a general approach Source: own compilation

1. Analysis of variations in the size of the three classes of units distinguished: growth areas, transition areas, and stagnation areas, together with their classification by the criterion of membership in the given class;

2. Analysis of development trajectories plotted on the basis of the synthetic index of socio-economic development in a general approach; and

3. Analysis of variations in the spatial distribution of areas of economic growth and stagnation at the local level using global and local Moran's I statistic and local indicators of spatial association (LISA) based on it ${ }^{3}$.

The results of the research procedure lead to the following conclusions. At the regional (NUTS 2) level, the broadest class throughout the study period was that of stagnation areas (a departure from this regularity was noted in 2000 when the

3 A detailed description of the method can be found in Janc (2006). class of transition areas was the largest). The number of voivodeships belonging to the class of stagnation regions varied between 7 (in 2000) and 10 units (in 2010). It should be emphasised that variations in the membership of individual units only involved shifts between the classes of stagnation and transition regions against an unchanging single-element composition of the class of growth areas (cf. Table 3 ).

When dividing voivodeships into classes of growth and stagnation areas, two large classes of equal size were obtained. Those are permanent transition areas, viz. those belonging to this class of socio-economic development over the entire period 2000-2010, and permanent stagnation areas, viz. those displaying the lowest development level in all the 11 observations (cf. Fig. 3). Permanent transition areas form two compact groups. One, longitudinal in orientation, extends from Pomerania through Wielkopolska to Lower Silesia. The other, of a latitudinal orientation, embraces Silesia and Małopolska. It should be emphasised 
Table 3. Size of classes of growth and stagnation areas at the NUTS 2 level in the years 2000-2010: a general approach

\begin{tabular}{|c|c|c|c|c|c|c|c|c|c|c|c|}
\hline \multirow{2}{*}{ Class of areas } & \multicolumn{11}{|c|}{ Number of voivodeships in the years: } \\
\hline & 2000 & 2001 & 2002 & 2003 & 2004 & 2005 & 2006 & 2007 & 2008 & 2009 & 2010 \\
\hline growth & 1 & 1 & 1 & 1 & 1 & 1 & 1 & 1 & 1 & 1 & 1 \\
\hline transition & 8 & 7 & 7 & 5 & 7 & 6 & 6 & 6 & 6 & 9 & 6 \\
\hline stagnation & 7 & 8 & 8 & 10 & 8 & 9 & 9 & 9 & 9 & 6 & 9 \\
\hline
\end{tabular}

Source: own compilation

that areas included in this class have relatively high indices of socio-economic development when seen against the national average. However, their figures are lower than those of Mazovia, which forms a one-element class of steady growth areas, mostly owing to the development dynamics of the Warsaw agglomeration located there. The regions included among permanent stagnation areas coincide with the 'eastern wall' and embrace Warmia-Mazuria, Podlasie, Lublin, Świętokrzyska Land and Subcarpathia, which show the lowest level of development by region both in Poland and the European Union.

The class of stagnation areas also includes three regions which fell to it at least seven times during the study period embracing 11 observations. Those are voivodeships forming a compact belt in western Poland and Łódź voivodeship in the centre which, despite public intervention, do not show the expected development dynamics because of a variety of structural problems they face: West Pomerania - liquidation of state farms, radical restructuring of the shipbuilding and fishing industries; Lubuska Land - an unfavourable financial situation of local government and enterprises combined with a great imbalance of the labour market; and Łódź - the fall of the textile industry. Also notable is the situation of the two remaining regions, Kujavia-Pomerania and Opole, which were classified as transition areas tending towards stagnation. It should be stressed that this does not follow from an absolute regression of those areas, but is rather a consequence of the greater development dynamics of the other voivodeships.

The distribution of the values of Perkal's synthetic index for each voivodeship in the years 2000-2010 makes it possible to identify their development trajectories. Differences in their socio-economic development widened, i.e. there was a growing divergence in the development, with various tendencies appearing within the classes of growth, transition and stagnation areas distinguished. In 2000 the synthetic index spanned a range of 1.23 (Mazovia - Świętokrzyska Land), while in 2010 it grew to 1.44 (Mazovia - Świętokrzyska Land again; cf. Fig. 4).

The growing development distance did not produce any change in the classification of regions in the best and the worst situation. The position of Mazovia as the development leader was unchallenged. This voivodeship had the highest values of the synthetic index throughout the study period, leaving behind those coming next, Lower Silesia and Pomerania, by an average of 0.46 points in 2000 and 0.56 points in 2010. It is worth observing here that since 2008 Lower Silesia had noted a steady upward trend (its development level giving it a position on the boundary of transition and growth areas), while Pomerania, less resistant to the consequences of unfavourable macroeconomic conditions, since 2009 had seen a decline in its development level making its promotion to the class of growth areas less probable.

The group of voivodeships classed as stagnation areas, in the worst situation, included Lublin, Podlasie and Świętokrzyska Land. All three noted an absolute decline in their development levels over the study period. Those that showed the greatest changes in the synthetic index were Lublin again, Opole and Silesia. In the case of Lublin, those changes deepened its regression and did not affect its position in the class of stagnation areas. In turn, Opole saw changes in its development level favourable enough to put it in the class of transition areas in the years 2003-2009. However, in 2009 its development trend started to weaken, which made it return to the class of stagnation areas to which it belonged in the period 2000-2002. Silesia recorded an upward trend, which markedly improved its position in the class of transition areas. 


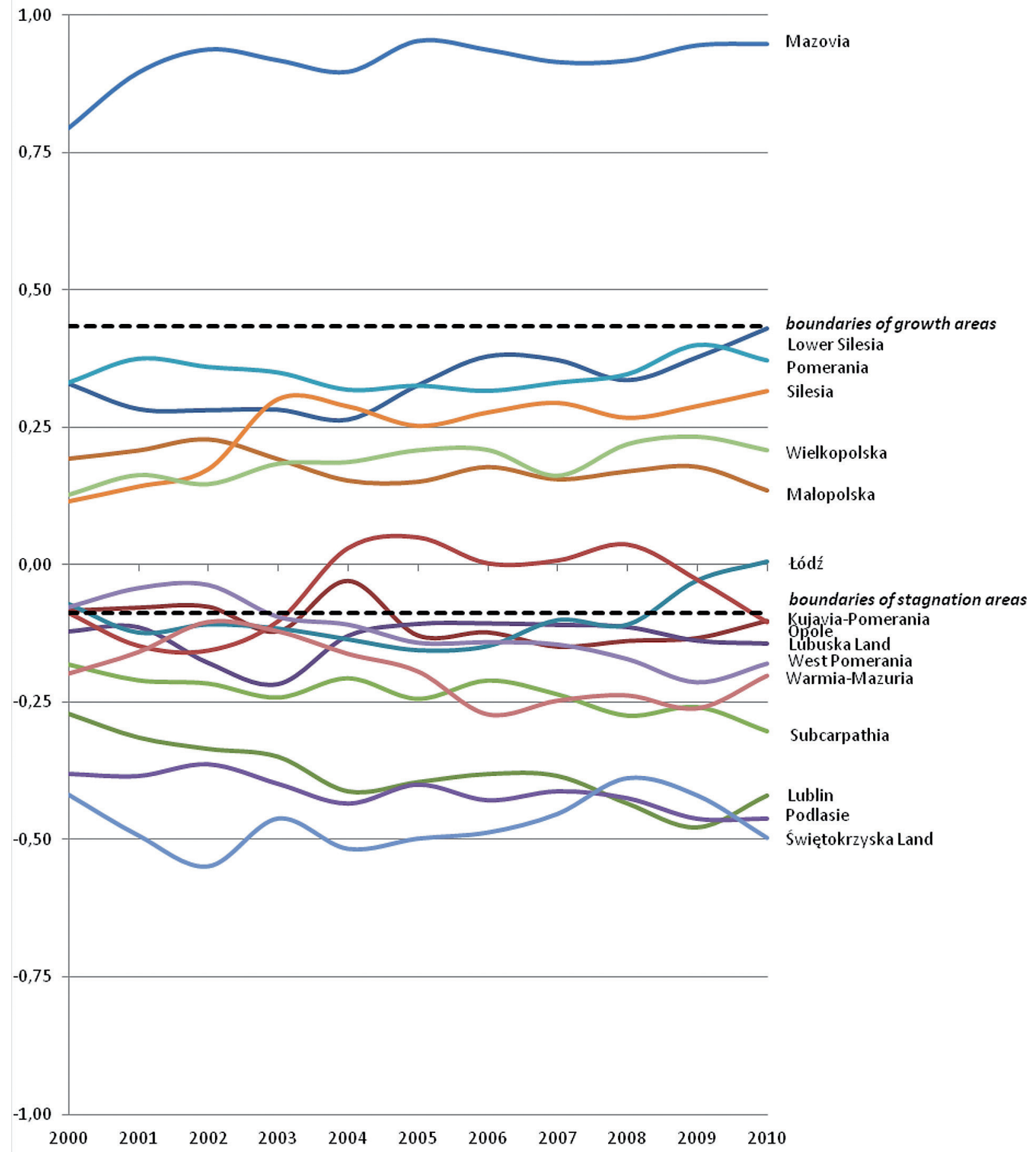

Fig. 4. Development trajectories of voivodeships in the years 2000-2010: a general approach Source: own compilation

The regions that saw the smallest changes in their development were Małopolska, Podlasie and Pomerania. In Podlasie and Pomerania those changes did not alter their positions against the remaining regions and their membership among, respectively, stagnation areas and transition areas. The situation was different in Małopolska, the position of which in the class of transition are- as worsened in spite of the relatively small variations in its development level. An interesting case is Łódź voivodeship: after an initial recession that caused it to fall from the class of transition areas to that of stagnation ones, since 2008 it had noted growth, which allowed it to return to the transition class. 
Table 4. Structure of classes of growth and stagnation areas by NUTS 4 units in the years 2000-2010: a general approach

\begin{tabular}{|c|c|c|c|c|c|c|c|c|c|c|c|}
\hline \multirow{2}{*}{ Class of area } & \multicolumn{11}{|c|}{ Share of poviats in the years } \\
\hline & 2000 & 2001 & 2002 & 2003 & 2004 & 2005 & 2006 & 2007 & 2008 & 2009 & 2010 \\
\hline growth & 21.1 & 20.3 & 20.6 & 20.3 & 23.0 & 23.0 & 23.2 & 23.2 & 23.0 & 21.9 & 20.6 \\
\hline transition & 46.4 & 48.0 & 48.3 & 48.5 & 43.5 & 41.4 & 40.6 & 41.2 & 42.2 & 42.7 & 44.3 \\
\hline stagnation & 32.5 & 31.7 & 31.1 & 31.1 & 33.5 & 35.6 & 36.1 & 35.6 & 34.8 & 35.4 & 35.1 \\
\hline
\end{tabular}

Source: own compilation

An analysis of the development trajectories of the Polish voivodeships also allows an assessment of their resistance to the economic slowdown. Those that kept an upward tendency in those global conditions are Lower Silesia, Silesia and Łódź in the class of transition areas, and Kujavia-Pomerania, West Pomerania, Warmia-Mazuria and Lublin in the class of stagnation areas. The regions which turned out to be less resistant to the crisis are Pomerania, Wielkopolska and Małopolska in the class of transition areas, and Opole, Lubuska Land, Subcarpathia and Świętokrzyska Land in the class of stagnation areas. There were two voivodeships that did not show any noticeable changes in their development trajectories which could be brought about by the economic slowdown: Mazovia in the class of growth areas and Podlasie in the class of stagnation areas.

At the local (NUTS 4) level, the biggest class throughout the study period was that of transition areas, whose share in the total number of poviats varied from $40.6 \%$ in 2006 to $48.5 \%$ in 2003 . The proportion of poviats belonging to the class of growth areas was the smallest: from $20.3 \%$ in 2001 and 2003 to $23.2 \%$ in the years 2006-2007. It should be emphasised that the proportions of the individual classes at the local level, as those at the regional one, showed great stability. However, at this level variations in the membership of individual units involved both, shifts between the classes of stagnation and transition areas, and shifts between the classes of growth and transition areas, the latter case not observed at the regional level (cf. Table 4). The results confirm that greater changes took place in the pattern of differences in socio-economic development in a general approach at the local level than at the regional one.

An important addition to the study of changes in the spatial distribution of areas of economic growth and stagnation over the study period in a general approach was an analysis of the values of global and local Moran's I statistic. The global Moran's I statistic was positive, which showed there to be a positive spatial autocorrelation and a tendency for the areas to form concentrations, or clusters. Also, the value of the statistic grew slowly but systematically, from 0.289 in 2000 , when it was at its minimum, to a maximum of 0.389 in 2008 (cf. Table 5, Fig. 5), while in 2010 one can observe a slight decline in the global $I$ statistic to 0.383 . This is evidence of ever stronger spatial links: on the one hand, of a growing spatial concentration of poviats at a similar development level, and on the other, of a growing impact of units on the situation in neighbouring poviats. The growing value of I statistic means that the distribution of Perkal's synthetic index by poviat started to depart from a random pattern. To make the analysis of global and local Moran's I statistic more detailed, use was made of an analysis of local indicators of spatial association (LISA) based on it. For this purpose, the first and last time moments were chosen as well as the years with the minimum and maximum values of global Moran's I that determined LISA values. Since the minimum was recorded in 2000, the analysis embraced the years 2000, 2008 and 2010. The distribution of clusters of spatial relationships thus obtained was very similar in

Table 5. Values of the global Moran's I statistic and its significance level by NUTS 4 units in the years 20002010: a general approach

\begin{tabular}{|c|c|c|c|c|c|c|c|c|c|c|c|}
\hline & 2000 & 2001 & 2002 & 2003 & 2004 & 2005 & 2006 & 2007 & 2008 & 2009 & 2010 \\
\hline Moran's & $\mathbf{0 . 2 8 9}$ & 0.322 & 0.316 & 0.329 & 0.348 & 0.346 & 0.355 & 0.382 & $\mathbf{0 . 3 8 9}$ & 0.368 & 0.383 \\
\hline P & 0.001 & 0.001 & 0.001 & 0.001 & 0.001 & 0.001 & 0.001 & 0.001 & 0.001 & 0.001 & 0.001 \\
\hline
\end{tabular}

Source: own compilation 

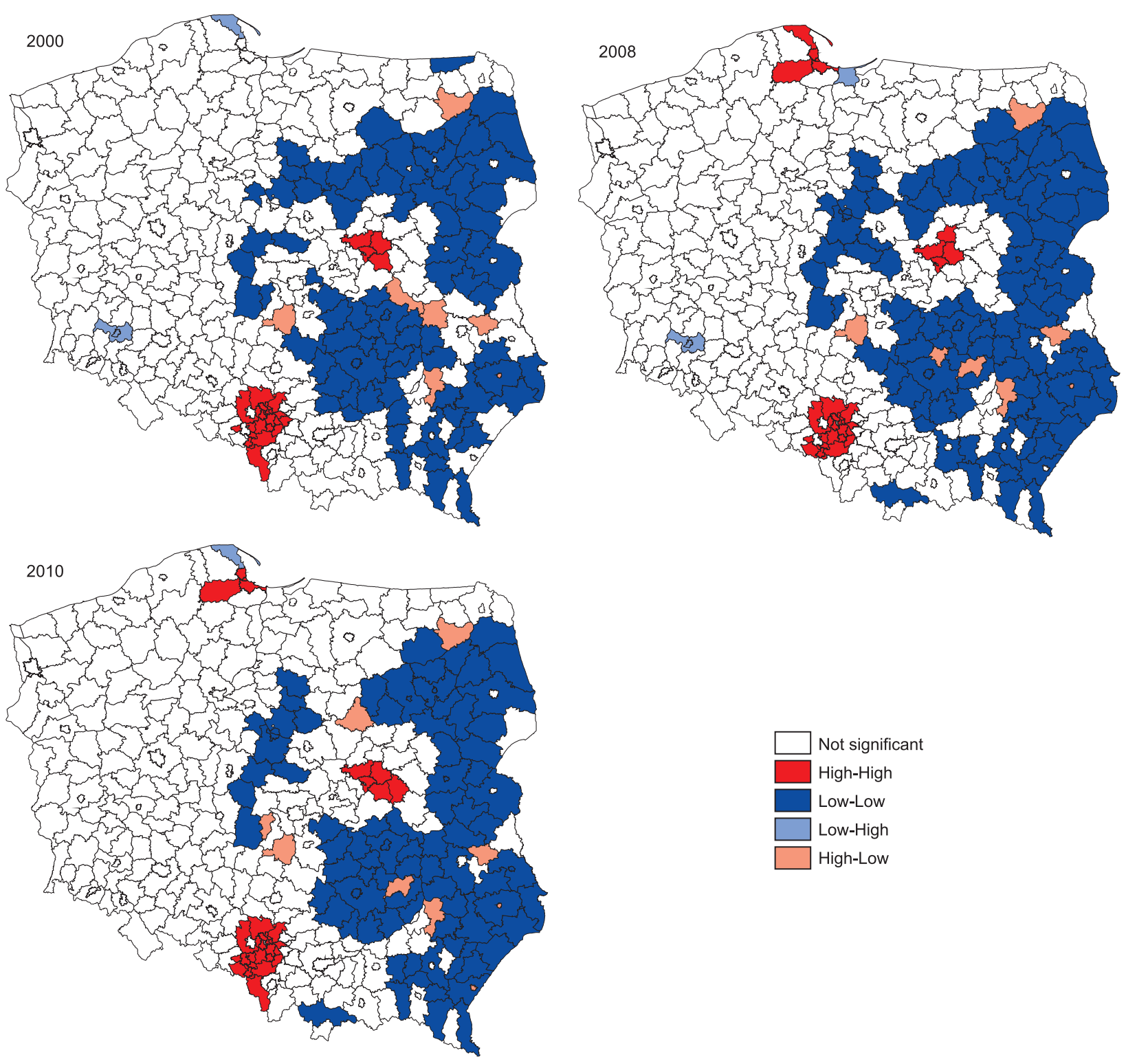

Fig. 5. Distribution of spatial dependence clusters established on the basis of LISA - local Moran's I statistic: a general approach Source: own compilation

all three observations. There were three distinct areas: Upper Silesia, the Warsaw agglomeration and the Tri-City, in which poviats with high values were surrounded by other poviats with high values (so-called hot spots). In turn, a marked tendency for the clustering of poviats at a low development level (so-called cold spots) could be found in eastern Poland, Łódź Land, northern Mazovia, and the eastern part of Kujavia-Pomerania (cf. Fig. 6). One can note that over the study period the number of poviats at a low development lev- el expanded in south-eastern Poland, in Subcarpathia, while it shrank in the north of Mazovia. Apart from those distinct clusters of a low development level, there were also smaller concentrations of this type. Both in 2008 and 2010 there was a clustering of poviats at a low development level in southern Małopolska, in Podhale. It should be stressed that those changes were usually a result of stagnation areas being slower in development than growth areas, rather than of their socio-economic situation worsening in absolute terms. 


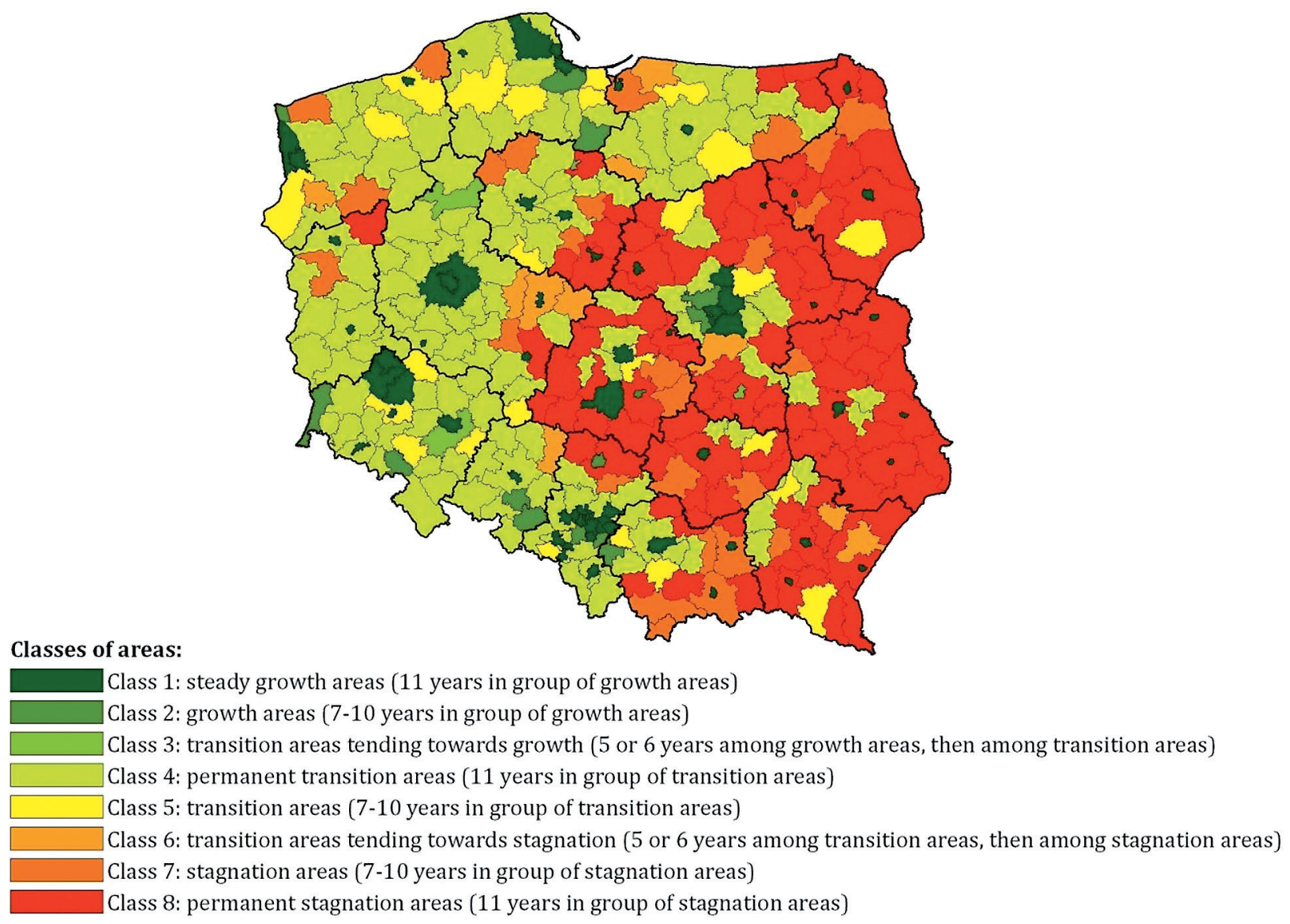

Fig. 6. Spatial distribution of classes of growth and stagnation areas by NUTS 4 units: a general approach Source: own compilation

The results of the analysis of the LISA distribution largely corroborate those of the analysis of variations in the distribution of areas of economic growth and stagnation. They show concentrations of poviats at a high development level in metropolitan areas (in the LISA distribution, high-development clusters in Upper Silesia, the Warsaw agglomeration and the Tri-City), and those at a low development level - in eastern Poland, Łódź Land, northern Mazovia, and south-eastern Kujavia and Dobrzyń Land (in the LISA distribution, low-development clusters). In the classification, as many as $78.9 \%$ of poviats kept their membership in one of the three classes over the entire 11 -year study period. Among them are $34.9 \%$ of poviats that stayed in the class of transition areas, $25.8 \%$ that belonged to stagnation areas, and only $18.2 \%$ that belonged to the growth group (cf. Fig. 6). Only $21 \%$ of poviats changed classes of socio-economic development in a general approach, with a mere $2.6 \%$ alternating between transition and stagnation areas, and $1 \%$ oscillating on the boundary between transition and growth areas. Their distribution displayed two regularities. Either those were areas situated in the neighbourhood of ones at a higher development level the diversified influence of which had led to shifts in their class membership - the effect of development diffusion. Or those were areas with significant endogenous resources, e.g. the so-called 'raw-materials' and 'industrial' poviats, in the case of which a poor or favourable economic situation of the chief, and often the only, employer significantly affected the development of the entire area and in effect its membership in a class of socio-economic development - the effect of a monofunctional economic base.

When analysing changes in the level of intra-regional differences in socio-economic development in a general approach by poviat, one should note the situation of Mazovia (cf. Table 6). The differences in the development level of poviats in this region far exceed those observed in other voivodeships. Besides, the range of those differ- 
Table 6. Range of values of Perkal's synthetic index for poviats by NUTS 2 units: a general approach

\begin{tabular}{|l|c|c|c|c|}
\hline \multirow{2}{*}{ Voivodeship } & \multirow{2}{*}{2000} & \multirow{2}{*}{2010} & \multicolumn{2}{c|}{ Maximum range } \\
\cline { 3 - 4 } & & 1.17 & 1.18 & year \\
\hline Lower Silesia & 1.14 & 1.38 & 1.38 & 2005 \\
\hline Kujavia-Pomerania & 1.14 & 1.39 & 1.43 & 2008 \\
\hline Lublin & 1.24 & 1.01 & 1.15 & 2005 \\
\hline Lubuska Land & 1.06 & 1.32 & 1.39 & 2006 \\
\hline Łódź & 1.30 & 1.26 & 1.34 & 2004 \\
\hline Małopolska & 1.07 & 2.43 & 2.43 & 2010 \\
\hline Mazovia & 2.13 & 1.00 & 1.06 & 2005 \\
\hline Opole & 0.92 & 1.35 & 1.60 & 2005 \\
\hline Subcarpathia & 1.29 & 1.35 & 1.46 & 2004 \\
\hline Podlasie & 1.46 & 1.72 & 1.72 & 2010 \\
\hline Pomerania & 1.33 & 1.42 & 1.59 & 2005 \\
\hline Silesia & 1.28 & 1.05 & 1.10 & 2009 \\
\hline Świętokrzyska Land & 0.88 & 1.24 & 1.36 & 2000 \\
\hline Warmia-Mazuria & 1.36 & 1.28 & 1.42 & 2006 \\
\hline Wielkopolska & 1.20 & 0.90 & 0.93 & 2001 \\
\hline West Pomerania & 0.91 & & & \\
\hline
\end{tabular}

Source: own compilation

ences increased from 2.13 in 2000 to 2.43 in 2010, which shows the intra-regional divergence of the largest region in Poland to be deepening. This is caused by socio-economic development progressing in the capital city while slowing down in the region's weakest poviats, especially Przysucha. Other voivodeships showing relatively wide contrasts in the intra-regional level of socio-economic development by poviat include Pomerania, Silesia and Subcarpathia, where the maximum range of values of the synthetic index exceeded 1.50 points over the study period. The region where the intra-regional differences in development by poviat were the slightest was West Pomerania, where the level of differences was also stable with a tendency towards convergence. In the entire set of 16 voivodeships, only four did not display a tendency towards deepening intra-regional differences, which is evidence of the advancing convergence of their development. Those were: Lubuska Land, with a decline in the development level of its growth areas; Warmia-Mazuria, with a rising development level of its stagnation areas; Podlasie, with a decline in the development level of both, growth and stagnation areas; and West Pomerania, with steady development tendencies persisting in both, growth and stagnation areas. The regions displaying a minimum of change with a tendency towards divergence were: Lower Silesia, with dynamic development of the region's capital, Wrocław; Łódź - with the development of 'raw-materials' poviats that are growth areas; Opole, with the development of the region's capital city of Opole and the weakening of its stagnation areas; Świętokrzyska Land, with a fluctuating pattern of development trajectories of its capital, Kielce; and Wielkopolska, with the dynamic development of growth areas, and especially its capital, Poznan. The widest differences in the intra-regional level of socio-economic development in a general approach in each of the voivodeships occur between non-municipal poviats and poviat-ranking towns. The scale of those differences also depends on the size of a region. Smaller voivodeships tend to show smaller differences in development. Larger ones display wider differences while suffering from underdevelopment of functional links with peripheral areas, which results, among other things, from the way they were delimited in 1999.

\section{Conclusions}

The results of the research procedure performed lead to the following conclusions and recommendations concerning the directions of intervention undertaken in the framework of cohesion policy:

- Growth areas in Poland correspond to metropolitan and highly industrialised areas. In the former, visible at the subregional level is their 
influence on the immediate surroundings, which confirms the spillover effect. In the case of the latter, this regularity is not observed. The intervention of development policy should seek to expand the range of influence of metropolitan areas and create such ranges in the case of the remaining growth areas, including those of industrial activity concentrations.

- The growing spatial extent of stagnation areas is not only an effect of a decline in their development level, but increasingly of their lower development dynamics in relation to metropolitan areas. Boosting their development dynamics should involve creating conditions for their absorption of development effects from growth areas. This should be the role of public intervention seeking to create and reinforce functional links. A tool helpful in its implementation in the perspective 2014-2020 can be the EU's Integrated Territorial Investment.

- The development policy pursued so far has proved to be of limited effectiveness in the convergence of socio-economic development at the regional level while producing a divergence noticeable at the local level. A new direction in cohesion policy for the years 2014-2020, resting on territorially integrated intervention, should pay more attention to innovativeness and the development of business environment institutions, factors currently greatly differentiating Poland's economic space, and to the development of instruments of financial support for entrepreneurs. In the conditions of limited possibilities of the absorption of means by local governments owing to their budget deficits, entrepreneurs should become important beneficiaries of the support granted, including that offered as part of the growing proportion of returnable instruments.

- The intervention intended to reinforce human capital pursued so far has proved to be hardly effective, as corroborated by how little influence the labour market situation and the structure of the economy seem to have on spatial differences in the general development level.

- The effect of the variable economic situation on growth dynamics differentiates socio-economic development at the subregional level more markedly than at the regional one, thus confirming the need to reinforce multifunctional development of the local economies.

Translated by Maria Kawińska

\section{References}

Aumayr Ch.M., 2007. European region types in EU-25. The European Journal of Comparative Economics 4(2): 109-147.

Chojnicki Z., Czyż T. (eds), 1991. Zróżnicowanie przestrzenne poziomu $i$ warunków życia ludności (Spatial differences in the population's level and conditions of living). Biuletyn KPZK PAN 153, Warszawa.

Churski P., 2012. Zróżnicowanie przestrzenne obszarów wzrostu i obszarów stagnacji gospodarczej w Polsce - wyzwania dla polskiej polityki spójności po 2013 r. (Spatial differences in areas of economic growth and stagnation in Poland: Challenges for the post-2013 Polish cohesion policy). In: Ciok S., Raczyk A. (eds), Wyzwania polityki regionalnej i lokalnej. Rozprawy Naukowe IGiRR UWr 27, Wrocław.

Cohesion Policy Support for Local Development. Best Practice and Future Policy Options. Final Report. Brussels, April 2010.

Dymnicki A.B., Henry D.B., 2011. Use of clustering methods to understand more about the case. Methodological Innovations Online 6(2), 6-26. http:// www.pbs.plym.ac.uk/ $\mathrm{mi} / \mathrm{pdf} / 31-08-11$ / 2.\%20Dymnicki\%20-\%20pp6-26.pdf

Faludi A., 2006. From European spatial development to territorial cohesion policy. Regional Studies 40(6): 667-678.

Fifth Report of Economic, Social and Territorial Cohesion. Investing in Europe's future. 2010. European Union Commission, Regional Policy, Luxembourg.

Identyfikacja i delimitacja obszarów problemowych i strategicznej interwencji w Polsce. Wnioski $z$ analiz (Identification and delimitation of problem areas and strategic intervention areas in Poland. Conclusions from analyses). 2009. Ministerstwo Rozwoju Regionalnego, Instytut Badań Strukturalnych, Warszawa.

Janc K., 2006. Zjawisko autokorelacji przestrzennej na przykładzie statystyki I Morana oraz lokalnych wskaźników zależności przestrzennej (LISA) - wybrane zagadnienia metodyczne (Spatial autocorrelation as exemplified by Moran's I statistic and local indicators of spatial association (LISA)). In: Komornicki T., Podgórski Z. (eds), Idee i praktyczny uniwersalizm geografii. Dokumentacja Geograficzna 33, IGiPZ, Warszawa: 76-83.

Kostrubiec B., 1965. Klasyfikacja dynamiczna i wielocechowa województw Polski (Dynamic and multivariate classification of Poland's voivodeships). Biuletyn KPZK PAN 35, Warszawa: 28-49.

Kronhalter F., 2003. A study of the competitiveness of regions based on cluster analysis: The example of East Germany. Halle Institute for Economic Research. Halle/Saale.

Krugman P., 1995. Development, geography, and economic theory (Ohlin Lectures). MIT Press, Cambridge, London.

Martin R., Sunley P., 2011. The new economic geography and policy relevance. Journal of Economic Geography 11(2): 357-369.

Meijers E.J, Waterhout B., Zonneveld W.A.M., 2007. Closing the gap: Territorial cohesion through polycentric development. European Journal of Spatial Development 24: 1-24.

Molle W., 2007. European cohesion policy. Routledge, London. 
Morrison D.F., 1990. Multivariate statistical analysis. McGrawHill, New York (3rd ed.).

Palme G., 1995a. Divergenz regionaler Konvergenzclubs. WIFO Monatsberichte 12(95): 769-781.

Palme G., 1995b. Struktur und Entwicklung österreichischer Wirtschaftsregionen. Mitteilungen der Österreichischen Geographischen Gesellschaft 137: 393-416.

Pakiet legislacyjny 2014-2020 (The 2014-2020 legislation package). http://ec.europa.eu/ regional_policy/ what/future/proposals_2014_2020_pl.cfm.

Regional development policies in OECD countries, 2010. OECD Report, Paris.

Reshaping economic geography, 2009. World Development Report, World Bank, Washington.
Regional policy contributing to sustainable growth in Europe 2020, 2011. Communication from the Commission to the European Parliament, the Council, the Economic and Social Committee and the Committee of the Regions. European Commission, SEC (2011) 92 final, Brussels.

Shrinking regions: A paradigm shift in demography and territorial development, 2008. Study - Regional Development, Policy Department B, Structural and Cohesion Policies, European Parliament, PE 408.928., Brussels.

Smith D., 1972. Geography and social indicators. South African Geographical Journal 54: 43-57.

Szymla Z., 2000. Determinanty rozwoju regionalnego (Determinants of regional development). Ossolineum, Wrocław.

Tryon R.C., 1939. Cluster analysis. Edwards Bros., Ann Arbor, MI. 